\title{
Wpływ technologii spawania laserowego na strukturę i właściwości złącza nadstopu niklu Inconel 625
}

\author{
The impact of laser welding technology on the structure \\ and properties of Inconel 625 nickel superalloy joint
}

\section{Streszczenie}

W pracy przedstawiono wyniki oceny jakości złączy spawanych laserowo rur ożebrowanych z nadstopu Inconel 625 stosowanych na wymienniki ciepła. W odniesieniu do składu chemicznego poddano ocenie mikro- i makrostrukturę złączy poprzez zastosowanie mikroskopii świetlnej. Stwierdzono, że zastosowanie spawania laserowego dla rur ożebrowanych przy odpowiednich parametrach spełnia wymagania towarzystw kwalifikacyjnych. Opracowana technologia umożliwiła uzyskanie złącza z pełnym przetopieniem o jednorodnym składzie chemicznym, wąskiej strefie ciepła i spoinie bez niezgodności spawalniczych.

Słowa kluczowe: nadstop Inconel 625, spawanie laserowe, rury ożebrowane

\section{Abstract}

The paper presents the results of the evaluation of the quality of finned tubes on laser welding technology of Superalloy Inconel 625 used in heat exchangers. Referring to the chemical composition has been evaluating microand macrostructure through the use of light microscopy. It has been found that the laser welding technology applied in the finned tubes meets the requirements set by the licensing authorities. The developed technology enabled one to obtain a joint with full penetration, of homogeneous chemical composition, a narrow heat-affected zone and a fusion weld area without welding imperfections.

Keywords: Superalloy Inconel 625, laser welding, finned tubes

\section{Wstęp}

Rozwój gospodarki jest związany z wykorzystywaniem coraz większej ilości energii elektrycznej. Powoduje to wzrost spalania węgla kamiennego i brunatnego w kotłach energetycznych, co zwiększa emisję dwutlenku węgla, dwutlenku siarki i szkodliwych pyłów do atmosfery. Dyrektywy wydane przez Unię Europejską narzucają na państwa członkowskie ograniczenie emisji gazów cieplarnianych, co wiąże się z poszukiwaniem nowych rozwiązań konstrukcyjnych. W tym celu konieczna jest modernizacja urządzeń oraz tworzenie nowych bloków na parametry nadkrytyczne i ultranadkrytyczne, które znajdą zastosowanie w przemyśle energetycznym. Rury ożebrowane z ciągłym czy też nacinanym żebrem, w zależności od parametrów eksploatacyjnych spalin i czynnika roboczego sprawdzają się jako podgrzewacze, przegrzewacze czy ekonomizery [1]. Obecnie stosowane rozwiązania konstrukcyjne energetycznych zespołów kotłowych posługują się spawanymi rurami ożebrowanymi do konstruowania wymienników ciepła, których sprawność jest 2,5 razy większa niż w przypadku rur gładkich. Do wytwarzania spawanych rur ożebrowanych stosuje się stale niskostopowe typu C-Mo, C-CrMo oraz stale niestopowe typu P235GH.

\section{Spawalność nadstopów Inconel}

Nadstopy Inconel, które należą do grupy Ni-Cr-Mo są dobrze spawalne, jednak muszą zostać spełnione pewne warunki. Konieczne jest zastosowanie odpowiedniego spoiwa oraz odpowiedniej metody spawania, a także przestrzeganie określonych wymagań technologicznych. Aby uniknąć powstawania pęknięć w złączach spawanych, zaleca się wykonanie wyżarzania odprężającego po procesie spawania. Materiały wykorzystywane do spawania stopów niklu obejmują spoiwa, topniki oraz gazy osłonowe. Do spawania stopów niklu stosowane są metody spawania łukowego: MIG, TIG, spawanie elektrodami otulonymi, tukiem krytym, plazmowe. Od niedawna do wytwarzania rur ożebrowanych stosuje się również spawanie laserowe. W celu usunięcia wilgoci z powierzchni spawanych przy spawaniu elementów w niskich temperaturach stosowane jest podgrzewanie w granicach $20-50{ }^{\circ} \mathrm{C}$ [2].

\section{Charakterystyka nadstopu niklu Inconel 625}

Inconel 625 to niemagnetyczny nadstop niklowo-chromowo-molibdenowy z dodatkiem niobu. Dodatek molibdenu

Dr hab. inż. Janusz Adamiec, prof. nzw. PŚl; mgr inż. Katarzyna Łyczkowska, dr inż. Agnieszka Tomaszewska - Politechnika Śląska. 
powoduje wysoką wytrzymałość bez konieczności utwardzania przez obróbkę cieplną. Jest materiałem trudno odkształcalnym, charakteryzuje się dużą podatnością na umocnienia podczas kształtowania metodami obróbki plastycznej [3]. Jest odporny na szereg środowisk silnie korozyjnych, a szczególnie na korozję wżerową i szczelinową. Znajduje zastosowanie w przemyśle chemicznym, inżynierii morskiej, przemyśle kosmicznym, na urządzenia do ochrony środowiska, urządzenia do kontroli zanieczyszczenia i w budowie reaktorów jądrowych $[4,5,6]$.

\section{Materiał do badań}

Badania przeprowadzono na złączach spawanych z nadstopu niklu Inconel 625. Oznaczenie, skład chemiczny i właściwości fizyczne nadstopu Inconel 625 przedstawiono w tablicy I. Widok rury ożebrowanej do badań przedstawiono na rysunku 1.

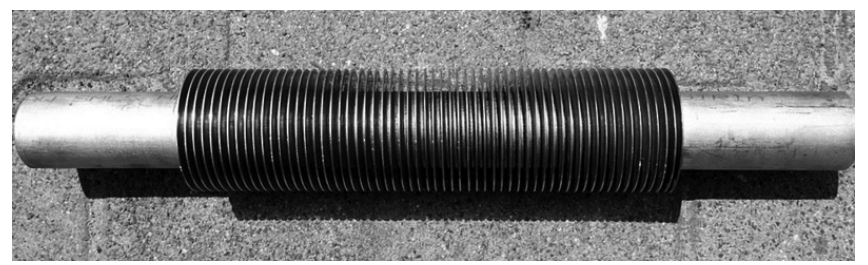

Rys. 1. Widok rury ożebrowanej z żebrem ciągłym z nadstopu niklu Inconel 625

Fig. 1. View of the finned tube with continuous ribs made of nickel superalloy Inconel 625

Próby spawania laserowego wykonano w Grupie Kapitatowej ENERGOINSTAL S.A. w Katowicach. W tym celu wykorzystano zrobotyzowane stanowisko firmy TRUMPF TruDisk 8002. Do spawania użyto światłowodowego systemu transmisji promieniowania laserowego z rezonatorem w głowicy roboczej oraz laserową głowicę spawalniczą z podwójną soczewką skupiającą o odległości ogniskowej $\mathrm{f}=300 \mathrm{~mm}$ i kolimator $300 \mathrm{~mm}$. Głównymi zmiennymi parametrami w procesie spawania laserowego były moc wiązki, która narastała od 2000 do $2600 \mathrm{~W}$ oraz prędkość spawania od 20 do $36 \mathrm{~cm} / \mathrm{min}$. Parametry spawania rur ożebrowanych z nadstopu Inconel 625 przedstawiono w tablicy II.

Tablica II. Parametry spawania rur ożebrowanych z nadstopu Inconel 625

Table II. Welding parameters for finned tubes of superalloy Inconel 625

\begin{tabular}{|c|c|c|c|c|}
\hline $\begin{array}{c}\mathrm{Nr} \\
\text { próbki }\end{array}$ & $\begin{array}{c}\text { Moc } \\
\text { lasera } \\
{[\mathrm{W}]}\end{array}$ & $\begin{array}{c}\text { Prędkość } \\
\text { spawania } \\
{[\mathrm{cm} / \mathrm{min}]}\end{array}$ & $\begin{array}{c}\text { Kąt 1 } \\
{\left[{ }^{\circ}\right]}\end{array}$ & $\begin{array}{c}\text { Kąt 2 } \\
{\left[{ }^{\circ}\right]}\end{array}$ \\
\hline 1 & 2600 & 20 & 16 & 12 \\
\hline 2 & 2500 & 20 & 16 & 12 \\
\hline 3 & 2200 & 36 & 16 & 16 \\
\hline 4 & 2000 & 28 & 16 & 12 \\
\hline
\end{tabular}

\section{Badania metalograficzne}

Do badań pobrano próbki, wycięte prostopadle do kierunku spawania bez naruszenia ich struktury. Na przygotowanie materiału składało się szlifowanie i polerowanie. Kolejno próbki trawione były w roztworze Lucas Reagent $(50 \mathrm{ml}$ kwasu mlekowego $+150 \mathrm{ml}$ kwasu $\mathrm{HCl}+3 \mathrm{~g}$ kwasu szczawiowego). Badania makroskopowe materiału wykonano za pomocą mikroskopu stereoskopowego SZX9, a ich wyniki przedstawiono na rysunku 2. Badania mikroskopowe zostały przeprowadzone na mikroskopie świetlnym Nikon Eclipse E200, w technice pola jasnego. Wyniki badań makrostruktury złączy spawanych laserowo na materiale Inconel 625 przedstawiono na rysunku 3. Niezgodności spawalnicze określono na podstawie PN-EN 13919-1 i EN ISO 6520-1.
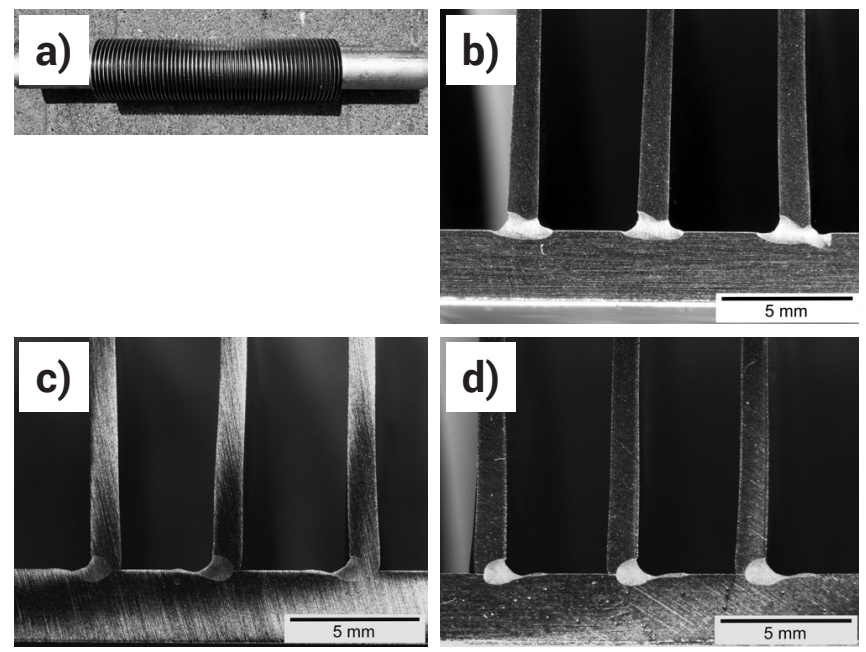

Rys. 2. Makrostruktura złączy spawanych laserowo na materiale Inconel 625: a ) próbka 1, b) próbka 2, c) próbka 3, d) próbka 4

Fig. 2. Macrostructure of laser welded joints on the material Inconel 625: a) sample 1, b) sample 2, c) sample 3, d) sample 4
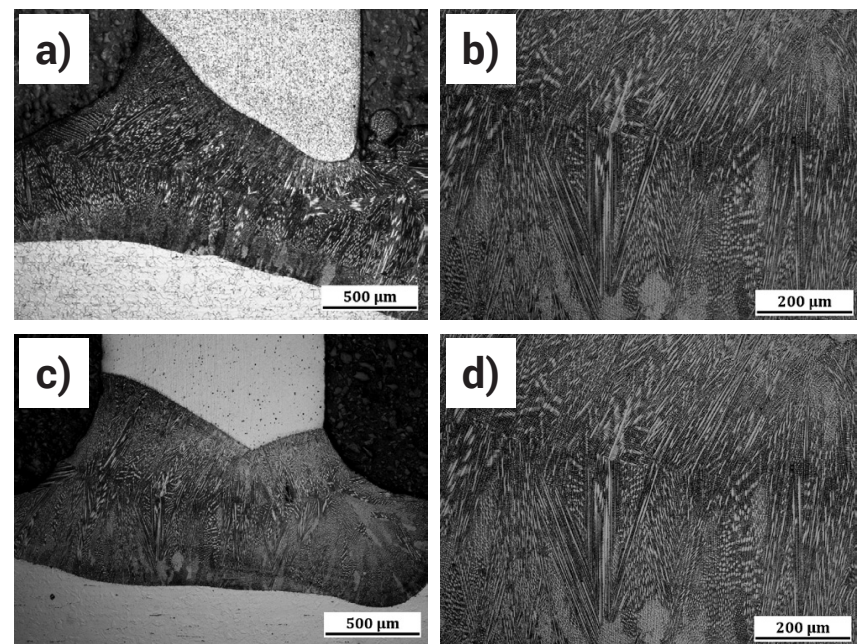

Rys. 3. Mikrostruktura spoiny wykonanej spoiwem Inconel 625 : a), b) próbka 1, c), d) próbka 2

Fig. 3. The microstructure of weld made with binder Inconel 625: a), b) sample 1, c), d) sample 2

Tablica I. Skład chemiczny nadstopu Inconel 625[3]

Table I. Chemical composition of superalloy Inconel 625[3]

\begin{tabular}{|c|c|c|c|c|c|c|c|c|c|c|}
\hline \multicolumn{10}{|c|}{ Skład chemiczny, \% } \\
\hline $\mathrm{Ni}$ & $\mathrm{Cr}$ & $\mathrm{Mo}$ & $\mathrm{Nb}$ & $\mathrm{C}$ & $\mathrm{Ti}$ & $\mathrm{Fe}$ & $\mathrm{Mn}$ & $\mathrm{S}$ & $\mathrm{Si}$ \\
\hline $58,0 \div 61,0$ & $20,0 \div 23,0$ & 9,0 & $\max$ & $\max$ & $\max$ & $\max$ & $\max$ & $\max$ & $\max$ \\
0,6 & 0,1 & 0,4 & 0,5 & 0,4 & 0,015 & 0,5 \\
\hline
\end{tabular}





Rys. 4. Mikrostruktura spoiny wykonanej spoiwem Inconel 625: a), b) próbka 3, c), d) próbka 4

Fig. 4. The microstructure of weld made with binder Inconel 625: a), b) sample 3, c), d) sample 4

\section{Podsumowanie}

Po przeprowadzeniu procesu spawania, w celu osiągnięcia optymalnych właściwości złączy próbki zostały poddane badaniom wizualnym, zgodnie z wymaganiami PN-EN 13919-1. Wykazano, że zwiększenie mocy do 2600 W i jednoczesne zmniejszenie prędkości spawania do $20 \mathrm{~cm} / \mathrm{min}$ wpływa pozytywnie na jakość złączy spawanych pozwalając na uzyskanie głębszego wtopienia spoiny wraz z łagodniejszym przejściem lica od żebra do rury. Obniżenie mocy lasera do poziomu 2000 W i zwiększenie prędkości spawania z 20 do $36 \mathrm{~cm} / \mathrm{min}$ ujawniło brak pełnego przetopu, co jest niedopuszczalne przez odbiorców rur ożebrowanych. Badania i analizy przeprowadzone na nadstopie niklu Inconel 625 wykazują strukturę Y'.

\section{Literatura}

[1] J. Adamiec, M. Więcek, G. Kokot, „Technologia spawania laserowego rur ożebrowanych", Przegląd Spawalnictwa, vol. 86 (5), s.3-9, 2014.

[2] Praca zbiorowa pod red. prof. hr. hab. inż. J. Pilarczyka, Poradnik Inżyniera - Spawalnictwo. Tom 2, WNT, Warszawa 2005.

[3] http://www.bibusmetals.pl/fileadmin/editors/countries/bmpl/Data_ sheets/Inconel_625_karta_katalogowa.pdf, 09.05.2015.

[4] J. Adamiec, E. Tasak, L. Tuz, K. Pańcikiewicz, „Ocena mikrostruktury wybranych stopów niklu" Przegląd Spawalnictwa, vol. 86 (5), s.64-67, 2014.

[5] Praca zbiorowa pod red. Prof. J. Pilarczyka, Poradnik Inżyniera - Spawalnictwo. Tom 1, WNT, Warszawa 2003.

[6] Z. Pakieła, Mikrostruktura i właściwości mechaniczne nadstopu Inconel 625, Obróbka Plastyczna Metali, nr 3, s.143-154, 2010. 